\title{
A Revogação da Sentença no Direito Brasileiro(*) (Perfil Histórico)
}

\author{
Moacyr Lobo da Costa \\ Professor Adjunto Aposentado
}

\begin{abstract}
SUMARIO: 13 - A controvérsia sobre a existência da ação de nulidade da sentença no direito brasileiro. - 13.1. A opinião de Pimenta Bueno. - 13.2. A opinião de Tristão Alencar Araripe. - 13.3. O incidente da nomeação de Tristão de Alencar Araripe para ministro do Supremo Tribunal Federal. 13.4. A opinião de F. Baltazar da Silveira e o acolhimento da tese de Tristão de Alencar Araripe pela jurisprudência do Supremo Tribunal de Justiça. 14. A elaboração do Regulamento n 737. - 14.1. Apreciação sobre o mérito do Regulamento no 737. - 15. A distinção entre nulidade do processo e nulidade da sentença. - 16. Os motivos de nulidade da sentenca. - 17. Os meios de impugnação da nulidade da sentença. - 18. O processo da ação rescisória. - 19. Aplicação do Regulamento n॰ 737 ao processo das causas cíveis com as excecões declaradas no Decreto no 763 , de 1890.
\end{abstract}

13. Em razão do preceito constitucional e dos dispositivos da lei de 18 de setembro de 1828, que criou o Supremo Tribunal de Justiça e lhe fixou a competência, e, das normas prescritas no Decreto de 20 de dezembro de 1830, para o cumprimento da lei de 18 de setembro, notadamente quanto ao processamento do Recurso de Revista e sua apresentação perante o Supremo Tribunal, para ser concedida ou denegada a revisão do julgado, nos dois exclusivos casos de manifesta nulidade ou injustiça notória da sentença, constituiu ponto duvidoso, sobre o qual lavrou séria divergência entre os juristas, o de ter permanecido, ou não, no direito brasileiro, o remédio ordinário contra a sentença nula, depois de haver sido julgado o Recurso de Revista.

Lembre-se que, a partir da autorizada exposição feita por Alvaro Valasco, na «Consultatio LI», ainda no regime das Ordenações Manuelinas, tornou-se pacífico entre os praxistas, comentadores e decisionistas o entendimento de concorrerem dois remédios contra a sentença eivada de nulidade, o ordinário «per viam nullitatis», e o extraordinário da Revista de Justiça, «remedium revisionis», sendo o remédio ordinário considerado imprescritível uma vez que a sentença nula nunca transitava em julgado, e, portanto, podia ser utilizado mesmo depois

(*) continuação do trabalho publicado no volume LXXIX. 
do julgamento da Revista, se o motivo da nulidade da sentença não foi discutido e decidido pelo Aresto proferido na Revista.

O remédio ordinário era uma sobrevivência da «querela nullitatis» do direito estatutário do século XIII, que ingressou no Direito Lusitano por intermédio da Lei das Sete Partidas no século XIV, e recebeu, no século XIX, a denominação de «ação de nulidade e rescisão da sentença» que lhe foi dada pelo artigo 17, da lei de 19 de dezembro de 1843 , o qual ampliou os casos de nulidade da sentença especificados no artigo $5^{\circ}$, do Decreto de 19 de maio de 1832, que a denominava simplesmente «ação de nulidade».

Em decorrência da terminologia empregada pelo legislador na redação do texto do artigo 17 , da Lei de 19 de dezembro de 1843 , a antiga ação de nulidade passou a ser conhecida por ação rescisória, «nomen juris» consagrado na doutrina dos processualistas portuguêses da segunda metade do século XIX.

Com o sistema introduzido pela lei de 19 de dezembro de 1843, ficaram diferenciados e bem delimitados os campos de cabimento e aplicação do Recurso de Revista e da ação de nulidade, ou rescisória, que eram os dois meios para se obter a revogação da sentença eivada de nulidade e consequente rescisão do julgado.

Tal sistema, entretanto, foi recebido com reservas e mereceu algumas ponderadas críticas dos processualistas portuguêses Corrêa Telles e Duarte Nazareth.

A independência proclamada pelo príncipe $\mathrm{D}$. Pedro libertou o país do jugo político e administrativo da Metrópole, mas não atingiu a cultura jurídica dos juristas brasileiros, que continuaram a se nutrir das idéias e das doutrinas professadas pelos autores portuguêses contemporâneos, por lhes serem comuns a formação e a língua.

É sobre a existência concorrente dessa ação de nulidade, ou rescisória, com o Recurso de Revista, e, especialmente, sobre a possibilidade de ser intentada após o julgamento da Revista, que se manifestou a divergência, em face do sistema instituido pelas leis brasileiras.

A propósito escreveu Pimenta Bueno: «Tem havido em nosso fôro graves dubiedades sobre a ação rescisória ou de nulidade das sentenças, entendendo alguns que a lei institutiva do Supremo Tribunal de Justiça, de 18 de setembro de 1828, posto que não expressa, todavia virtualmente revogou os diversos títulos de nossas Ordenações e mais leis que autorizavam o uso das sobreditas ações. São dúvidas de muito alcance ou transcendência, pois que importam altos interesses, que a lei deve resguardar, não deixando que elas subsistam por mais tempo».

Em seguida, manifestou sua opinião no sentido de que, enquanto a lei não terminar a dubiedade, continuaria ele a entender que só se achavam revogadas tais ações nos casos em que elas são incompativeis com o sistema de revistas, que a legislação brasileira estabeleceu, «mas não nos casos em que não só deixam de ser incompatíveis, mas em que a 
lei as deveria criar quando mesmo elas ainda não existissem autorizadas». («Apontamentos sobre as Formalidades», cit. p. 119)

O Conselheiro José Antonio da Silva Máia, Procurador da Corôa, Soberania e Fazenda Nacional respondendo a uma consulta sobre essa questão, declarou no Aviso de 12 de fevereiro de 1841, que «a matéria era duvidosa».

Se o próprio Procurador da Corôa reconhecia a existência de dúvida ante a indefinição das leis em vigor, não admira que sobre a questão divergissem as opiniões dos homens do fôro.

Um dos mais respeitados advogados na Corte, o jurista Caetano Alberto Soares, publicou na Gazeta dos Tribunais, de 14 de junho de 1843, um bem elaborado artigo sobre o assunto, argumentando vivamente contra a admissibilidade da ação rescisória de sentenças em gráu de revista.

Com a declarada finalidade de pôr termo a essa situação de incerteza e resolver em definitivo a questão, outro eminente jurista propôs, no Projeto de Lei que elaborou para a reforma do Supremo Tribunal de Justiça, que o julgamento do Recurso de Revista pelo Supremo fosse definitivo e suas sentenças irrevogáveis. (art. 12)

Carvalho Moreira declarou enfaticamente na Memória oferecida ao Instituto da Ordem dos Advogados Brasileiros, em 1847, para jus tificar o Projeto: «Foi minha idéia terminar por uma vez com as ações rescisórias, cuja legalidade é mesmo problemática, ou pelo menos duvidosa». (Memória, cit. p. 20)

Em apoio da solução preconizada no Projeto, o futuro Barão de Penedo transcreveu por inteiro na Memória o artigo de Caetano Alberto, precedido da seguinte advertência: «Não podendo desenvolver a minha opinião melhor, nem mais valentemente do que foi pelo nosso distinto e sábio colega, o Sr. Dr. Caetano Alberto Soares, translado aqui a sua argumentação de um luminoso artigo publicado na Gazeta dos Tribunais, de 14 de junho de 1843».

13.1. A questão da admissibilidade da ação rescisória contra a sentença nula permaneceu em aberto, a despeito das autorizadas manifestações em contrário.

Nos «Apontamos sobre as formalidades do Processo Civil», cuja $1^{\text {a }}$ edição foi publicada em 1850, Pimenta Bueno desenvolveu a mais cabal e convincente argumentação em prol do prevalecimento da ação de nulidade ou rescisória no direito brasileiro.

Começou ele por examinar as leis portuguesas que disciplinam o cabimento dessa ação nos casos taxativamente indicados, nos artigos $5^{\circ}$, do Decreto de 19 de maio de 1832 , e 17, da lei de 19 de dezembro de 1843, cujos enunciados transcreveu, e reportou-se, também, ao artigo 480 e seus parágrafos, do Código de Processo Civil francês, que admite este meio extraordinário sob a denomição de «requete civile», 
«não só nos mesmos casos em que o faz a legislação portuguesa, mas ainda em outros». («Apontamentos», cit. n० 229)

Depois de acentuar que segundo o nosso direito atual não há unidade de opinião em nosso fôro, lembrou que o Conselheiro Procurador da Corôa havia declarado que a matéria era duvidosa, e, entretanto, o Governo até hoje ainda não provocou medida legislativa para sanar a dúvida.

No seu entender a ação de nulidade prevalece, tenha ou não havido Revista, «nos seguintes casos, que não só não são incompatíveis com o sistema das revistas, mas que demandariam tal ação quando ela não estivesse já instituída por nossas leis».

Quatro são os casos que por sua relevância justificam o prevalecimento da ação de nulidade ou rescisória.

Primeiro, «quando verificar-se que a sentença foi dada por peita, suborno ou prevaricação, uma vez que esta só seja conhecida ou a responsabilidade quando intentada só seja julgada afirmativamente, já depois que não tiver lugar qualquer outro recurso».

Em comentário a esse primeiro caso observa, incisivamente, que, «em verdade não seria um escândalo em vez de justiça, e uma subtileza ridícula em vez de razão esclarecida, reconhecer a prevaricação do julgador, e sustentar o seu ato imoral e criminoso?»

«Como conciliar a sentença criminal que o punisse com a irrevogabilidade do ato que serve-lhe de corpo de delito?»

Segundo, «no caso de ter sido a sentença proferida em virtude de documentos reconhecidos como manifestamente falsos, uma vez que a falsidade seja conhecida somente depois de proferida a sentença, e quando já não era admissivel nem um outro recurso».

A respeito deste segundo caso, formula três percucientes indagações: "como reconhecer a falsidade, a fraude ou dolo, e cometer a grave injustiça de não restituir a propriedade a seu legitimo dono?»

«De que proveito são os recursos anteriores para reprimir a falsidade no caso de ser esta reconhecida só depois deles expirarem-»

«Negar-se-á também a ação criminal, e o direito a satisfação do dano, ou sustentar-se-á sentenças entre si contraditórias?»

Terceiro, «o caso de produzir a parte, depois de extintos os recursos, documentos preexistentes, mas não conhecidos, ou ocultados pela parte contrária, e tais que destruam completamente a prova em que a sentença fundou-se». Este caso está na mesma condição da hipótese anterior.

Glosando-o, acentua que «se havia uma impossibilidade de a parte prejudicada em produzir antes esses documentos, ou a málicia de seu adversário em ocultá-los, como a justiça dos homens há de decre- 
tar que ela perca (no original está grafado perda) sem culpa sua os seus direitos?"

Quarto, "finalmente, quando a parte condenada sem ter sido ouvida, provar que houve falta, ou falsidade da primeira citação". "Como sustentar a pezar disso o julgado?»

Com relação a cada um desses quatro casos Pimenta Bueno indicou com pertinência os dispositivos das Ordenações que lhes servem de fundamento, bem como as passagens dos livros de Mello Freire e de Pereira e Sousa, que tratam dessas questões.

Ora, escreveu como remate de sua argumentação, "se estes casos se acham previstos por nossas leis, se a que instituiu o sistema das revistas não as revogou expressamente, e nem tão pouco virtualmente, pois que não há entre elas incompatibilidade alguma, porque vacilaremos nós outros em dúvida?"

«Se não tivessemos nessa parte as previsões de nossas Ordenações, deveríamos criar essas previdentes disposições, e tendo-as deveremos anulá-las? Faremos o inverso do que praticam as legislações estrangeiras, que temos referido?» («Formalidades» cit. p. 122)

Os argumentos de Pimenta Bueno jamais foram refutados.

Sua memorável lição se encerra com estas palavras de alta sabedoria, das mais sérias e das mais verdadeiras que a literatura processual brasileira registrou para sempre:

«E sem dúvida de mister consagrar a autoridade da coisa julgada, mas não é menos essencial consagrar o império da verdade e da justiça, quando se patenteia tal que não se pode dele duvidar».

«Nas ciências morais poucas vezes é permitido levar as disposições humanas ao absoluto, sem que se cometam algumas e graves injustiças: convém evitá-las».

De par com a ciência do jurista estas palavras revelam a visão do estadista, que viria a ser um dos maiores do Imperio.

13.2 A controvertida questão continuou a ser discutida com relação ao processo das causas cíveis, uma vez que para as causas comerciais o legislador, em 1850, cortou cerce a dúvida, proibindo a ação rescisória contra sentença proferida em gráu de revista.

O Regulamento $\mathrm{n}^{\circ} 737$, editado para reger o processo das causas comerciais, foi elaborado por uma Comissão de que faziam parte os juristas Caetano Alberto e Carvalho Moreira, tendo sido este último o redator exclusivo do texto definitivo daquele diploma.

A norma do $\S 4^{\circ}$, do artigo 681 do Regulamento, é, assim, o coroamento legislativo da opinião conhecida e publicada daqueles dois juristas, contrária à admissibilidade da ação rescisória contra sentença proferida em gráu de revista. 
O Regulamento, porém, era restrito ao processo comercial.

Não faltaram vozes, então, no sentido de propugnar a extensão da norma proibitiva a todas as sentenças proferidas em gráu de revista, sob o argumento de ter o direito brasileiro erigido o julgamento da revista pelo Supremo Tribunal em pronunciamento último e definitivo do Poder Judiciário sobre a causa, e, que sendo esse o fundamento da nova norma, sua aplicação não podia ser limitada às causas comerciais.

Nessa linha de raciocínio e com tal finalidade, o conhecido jurista Conselheiro Tristão Alencar Araripe publicou na revista mental «O Direito», em 1875, um artigo doutrinário destinado a demonstrar que a ação rescisória não pode ser indistintamente admitida no processo civil brasileiro, notadamente contra as sentenças a que o Supremo Tribunal negou o Recurso de Revista e contra as que foram proferidas nas Relações revisoras.

Começa o artigo por lembrar que a legislação herdada de Portugal admitia que as sentenças civis, embora passadas em julgado, pudessem ser atacadas em todas as circunstâncias por via de ação rescisória, isto é, facultava o direito de inutilizar uma decisão suprema, não obstante haver esta percorrido todos os trâmites judiciários.

Esta doutrina, acentuou o articulista, tem sido aplicada entre nós sem limitação, «mas julgamos errônea essa aplicação da Lei antiga sem a restrição que lhe impõe a legislação moderna», afirmando enfática e dogmaticamente: «Tenho por certo que no Brasil as sentenças que sofreram revista não podem ser cassadas ou nulificadas por meio de ação rescisória».

Para demonstração de sua tese, desenvolveu cerrada argumentação centrada na natureza do julgamento do Recurso de Revista pelo Supremo, nos dois casos de manifesta nulidade ou injustiça notória da sentença, aduzindo que «admitir que o legislador, concedendo a revista para esse fim, permite que depois as partes continuem a contender sobre esses mesmos vícios, é admitir uma inutilidade, se não uma inépcia da lei.»

Invocando a seguir a situação criada para as causas comerciais, que evidenciava, a seu ver, ser esse, também, o entendimento do Governo, recorreu ao argumento analógico, que apresentou como decisivo. «No Regulamento Comercial de 25 de novembro de 1850 , se determina que as causas mercantis julgadas em revista não ficavam sujeitas à ação rescisória».

«Ora, ao poder executivo não cabia por sua própria autoridade revogar as Ordenações citadas».

«Logo quando assim estatuiu foi obrigado pelas disposições do nosso direito novo».

«Se porém o direito novo prevalece para as causas comerciais, deve também prevalecer para as demais causas civeis». 
«A força dispositiva é a mesma quer para uma natureza de causas quer para outra: abrange a ambas». (in «O Direito, Revista Mensal de Legislação e Jurisprudência», 1875, vol. VI p. 150).

13.3 O autor do artigo foi mais tarde Ministro do Supremo Tribunal de Justiça do Império, até sua extinção, e, nos primórdios do regime republicano, viu-se envolvido num incidente deslustroso de sua reputação.

A convite do Marechal Deodoro, de quem era amigo pessoal, substituiu a Ruy Barbosa na pasta da Fazenda do Governo Provisório, e nela permaneceu no governo constitucional do Marechal, até julho de 1891. Não obstante sua condição de Ministro da Fazenda foi incluido na lista dos primeiros 15 Ministros nomeados pelo Marechal, pelo decreto de 12 de novembro de 1890, para o recem criado Supremo Tribunal Federal.

Submetidas as nomeações à aprovação do Senado, como determinava a lei de 11 de outubro de 1890, que criou o Supremo Tribunal Federal, foi lido na sessão secreta do Senado, de 7 de julho de 1891, o parecer da Comissão de Justiça contrário à aprovação dos nomes do Barão de Lucena e de Tristão de Alencar Araripe, «nos quais, por circunstâncias e fatos notórios, a Comissão deixa de reconhecer a precisa idoneidade para o desempenho imparcial e justo dos grandes deveres e atribuições que lhes adviriam de tão elevado encargo». Assinam o parecer os senadores Gomensoro e Amaro Cavalcanti.

Segundo Amaro Cavalcanti, a Comissão impugnou aquelas duas nomeações porque os nomeados «como membros do Governo têm abusado de suas posições políticas e da confiança do Presidente da República, violando acintosa e caprichosamente muitas disposições da Constıtuição. Quem viola a Constituição não pode ser o guarda vigilante das leis e dos próprios preceitos constitucionais». (Cf. Leda Boechat Rodrigues, «História do Supremo Tribunal Federal», vol. I, 1891-1898, p. 12; Aliomar Baleeiro, «O Supremo Tribunal Federal, esse outro desconhecido», Forense 1968, p. 22).

As nomeações foram confirmadas, inclusive com o voto favorável de Ruy Barbosa, que, mesmo reconhecendo a incompatibilidade de ser nomeado Ministro do Supremo Tribunal quem na época era Ministro do Governo, e, «reconhecida a incompatibilidade deveríamos agora decretá-la», acabou curvando-se aos «altos sentimentos patrióticos», como declarou da tribuna, pois «em assuntos políticos, as razões devem ceder e curvar-se a altos sentimentos patrióticos, assinalando dia a dia o nosso espírito profundamente pacificador». (in «Obras Completas» vol. XVIII, 1891, tomo I p. 152)

A 8 de janeiro de 1892, o deputado César Zama apresentou à Câmara um projeto de lei eliminando do Supremo Tribunal os nomeados Ministros Barão de Lucena e Alencar Araripe e inabilitando-os para o exercício de qualquer função pública em todo o território nacional. O 
projeto foi julgado inconstitucional na sessão de 18 de janeiro e, por 53 contra 50 votos, não objeto de deliberação. Sete dias depois, a 25 de janeiro de 1892 foi publicado o decreto de aposentadoria dos dois ministros. (Leda Boechat Rodrigues, «História» cit. p. 13 nota 12)

Mesmo tendo assinado o termo de posse, na sessão de instalação do Supremo Tribunal Federal de 28 de fevereiro de 1891, o Ministro Alencar Araripe não assumiu efetivamente o cargo e não chegou a desempenhar no Tribunal republicano as funções que desempenhara no seu congênere do Império.

13.4 A discussão doutrinária em torno da controvertida questão continuou propiciando aos juristas a exposição de suas opiniōes, em trabalhos estampados na revista «O Direito», que era na época o veículo especializado na divulgação de toda atividade relacionada com o direito, mediante publicação regular de leis, decretos, avisos, sentenças, acordãos, arrazoados forênses e artigos de doutrina.

Num pequeno artigo intitulado «Ação Rescisória», publicado em 1876, o doutor Francisco Balthazar da Silveira indaga, «que fundamento tem a opinião dos que sustentam que, decidida uma causa em gráu de revista, não pode mais ter lugar a ação rescisória?».

Sem o nomear, o escrito era uma resposta crítica à opinião de Alencar Araripe.

Depois de assentar que não adota semelhante opinião, o doutor Balthazar escreve: «Tenho como líquido, certo, que não há dísposição legal que tenha acabado a ação rescisória; e bastaria a terminante determinação da Ord. Liv. $3^{\circ}$ Tít. 75 pr. que precisa de especial e clara revogação, para que não mais regule.»

«E se houvesse necessidade de mais força, ai estão os Avisos 61 e 85, de 6 de março e de 2 de abril de 1849. E temos, também, a opinião bem moderna de Pimenta Bueno (hoje Marquez de São Vicente) nas «Nulidades» etc. à 11, 13 e 93, sem que haja necessidade de invocar Mello Freire e outros.»

Em seguida passa a refutar o argumento analógico: «O preceito final do art. 681 , do Regulamento $\mathrm{n}^{\circ} \mathbf{7 3 7}$, de 1850 , não pode ser trazido para se estabelecer que não há ação rescisória quando a sentença tenha sido proferida em gráu de revista, porquanto é determinação especial para o fôro comercial, improrrogável.»

«Pelo contrário, é bem evidente prova de se não achar extinto um tão essencial e extraordinário meio de se desfazer uma sentença nula, iniqua, remédio estabelecido para o uso geral, para as nulidades de todo o fôro.» (in «O Direito», 1876, vol. 9 p. 212)

A tese que acabou sendo acolhida pelo Supremo Tribunal foi, no entanto, a sustentada por Tristão Alencar Araripe. 
No princípio por maioria, pois alguns Ministros entendiam serem as normas do Regulamento $n^{\circ} 737$ de aplicação restrita ao processo das causas comerciais. Depois, por unanimidade.

No ano de 1878, o Supremo Tribunal enfrentou a questão por duas vezes e proferiu duas decisões, que firmaram a jurisprudência a respeito, assentando o entendimento de que a disposição do $\S 4^{\circ}$ do art. 681 do Reg. $\mathrm{n}^{\circ} 737$, de 1850 , é aplicável tanto às causas comerciais como às causas cíveis, por não conter uma simples fórmula do processo em juizo comercial, mas sim a verdadeira inteligência da lei de 18 de setembro de 1828 e decreto de 10 de dezembro de 1830 .

$\mathrm{Na}$ primeira decisão, de 24 de agosto de 1878, por maioria, foi concedida a revista por injustiça notória e consequente nulidade manifesta dos acórdãos recorridos, sob o fundamento de que «a ação de nulidade ou rescisória, fundada na Ord. Liv. 3 Tit. 75 pr. não é admissivel da sentença de que se tiver manifestado revista, fosse ou não concedida; porque, sendo esta, como aquela, meios ordinários de emendar a nulidade dos julgados por um novo julgamento, é conforme a direito, que a escolha de um prejudique ao outro, e assim expressamente o declara o art. 681, no $\S$ $4^{\circ}$, do decreto $\mathrm{n}^{\circ} 737$, de 25 de novembro de 1850 , cuja disposição é aplicável tanto às causas cíveis como às comerciais, por não conter uma simples fórmula do processo em juízo comercial, mas sim a verdadeira inteligência da lei de 18 de setembro de 1828 e decreto de 20 de dezembro de 1830 , de acordo com a citada Ord. Liv. $3^{\circ}$ Tit. 75 , como já propusera o procurador da corôa, no parecer que acompanha o Aviso de 12 de fevereiro de 1841, para evitar as dúvidas que a respeito suscitaram-se e a divergência dos julgados; além de que, onde se dá a mesma razão deve-se dar a mesma disposição de direito, como diz o $\$ 11$ da lei de 18 de agosto de 1769." - votaram vencidos os Ministros Couto, Silveira, Almeida e Travassos (in «O Direito», 1878, vol. 17 p. 712,713 )

Na segunda decisão, de 20 de novembro do mesmo ano, o Supremo Tribunal reiterou o entendimento manifestado no julgamento de 24 de agosto, pelos mesmos fundamentos, mas desta vez por unanimidade de votos.

Como razão de decidir pela concessão da revista, declara o acórdão que "a disposição da Ord. Liv. $3^{\circ}$ Tit. 75, que autoriza a ação de nulidade ou rescisória das sentenças de que se tiver ou não apelado, não é aplicável às de que se tiver manifestado revista e se tiver pronunciado este Supremo Tribunal de Justiça sobre sua validade ou nulidade, concedendo ou negando revista, pois, que sendo uma e outra meios ordinários de emendar-se a nulidade por um novo julgamento, é conforme o direito, que o uso de um prejudique o outro, e assim expressamente o declaram os artigos $581 \S 2^{\circ}$ e $681 \S 4^{\circ}$, do Reg. $n^{\circ} 737$, de 25 de novembro de 1850 , cuja doutrina é aplicável tanto às causas cíveis como comerciais, por conter a verdadeira inteligência da lei 
de 18 de setembro de 1828 e decreto de 20 de dezembro de 1830 , de acordo com a Ord. Liv. $3^{\circ}$ Tit. 75 e 87; e porque é princípio consignado na lei de 18 de agosto de $1769, \S 11$ e outros, que onde se dá a mesma razão deve aplicar-se a mesma disposição de direito.» (in «O Direito», 1879, vol. 18 p. 76, 77) )

A jurisprudência do Supremo Tribunal, proclamando que as decisões proferidas em gráu de revista não podiam ser revogadas por ação rescisória, qualquer que fosse a natureza da ação, civil ou comercial, representava, embora tardiamente, o acolhimento da doutrina professada por Caetano Alberto e Carvalho Moreira, em 1843 e 1847, respectivamente.

O dispositivo do $\S 44^{\circ}$, do art, 681 do Regulamento $n^{\circ} 737$, vedava a ação rescisória em relação à "sentença proferida em gráu de revista», ou seja, à sentença que decidiu sobre a nulidade da sentença recorrida, e que foi objeto do recurso de revista, com a finalidade de tornar definitivo e irrecorrivel o julgamento da nulidade arguida.

Os doutrinadores e os Ministros do Supremo não atentaram para a possibilidade de ocorrer uma nulidade em relação ao ato de julgamento da revista, no Supremo Tribunal, ou na Relação revisora, e, então, ser necessária a ação rescisória para reparar a nulidade superviniente em gráu de revista, que não se confundia com a nulidade que constituira o fundamento do recurso.

Figure-se a hipótese de suborno de Ministro do Supremo, ou Desembargador da Relação revisora, que tenha julgado a revista com voto vencedor.

A hipótese não é inverosímel. Não é por ter assento nas altas Côrtes de Justiça que o homem se torna imune à corrupção. Nem por ser proferida por órgão supremo a decisão será escorreita, insuscetível de incorrer em nulidade.

A decisão proferida em gráu de revista não pode ser elevada à categoria de absoluta, para não ensejar a consagração de alguma grave injustiça, que convém evitar-se, como sabiamente disse Pimenta Bueno. Seu ensinamento, contudo, só veio a ser atendido na República, quando foi estabelecida a competência da Justiça Federal para julgar as ações rescisórias das decisões do Supremo Tribunal Federal.

14. Com a lei $n^{\circ} 556$, de 25 de junho de 1850 , foi promulgado o Código Comercial, que atendendo aos reclamos da prestigiosa classe dos comerciantes, se destinava a disciplinar sua atividade lucrativa segundo normas jurídicas adequadas, a exemplo do Código de Comércio francês de 1807.

O Código terminava com um Título único, subdividido em dois capítulos com 28 artigos. O primeiro Capítulo, «Dos Tribunais e Juízos Comerciais.» artigos 10 a 21; o Segundo, Capitulo «Da Ordem do juízo nas Causas Comerciais», artigos 22 a 28. 
Neste Segundo Capitulo foram estabelecidas as seguintes regras processuais:

«Art. 22. Todas as causas comerciais devem ser propostas, em todos os Juízos e instâncias, breve e sumariamente, de plano e pela verdade sabida, sem que seja necessário guardar estritamente todas as formas ordinárias prescritas para os processos cívis: sendo unicamente indispensável que se guardem as fórmulas e têrmos essencias para que as partes possam alegar o seu direito e produzir as suas provas."

«Art. 23. Não é necessária a conciliação nas causas comerciais que procederem de papéis de crédito comerciais que se acharem endossados, nas em que as partes não podem transigir, nem para os atos de declaração de quebra.»

"Art. 24. Nas causas comerciais só se exige que seja pessoal a primeira citação, e a que deve fazer-se no princípio da execução.»

«Art. 25 Achando-se o réu fora do lugar onde a obrigação foi contraída, poderá ser citado na pessoa de seus mantadários, administradores, feitores e gerentes, nos casos em que a ação derivar de atos praticados pelos mesmos mandatários, administradores, feitores ou gerentes. O mesmo terá lugar a respeito das obrigações contraídas pelos capitães ou mestres de navios, consignatários e sobrecargas, não se achando presente o principal devedor ou obrigado.»

«Art. 26 Não haverá recurso de apelação nas causas comerciais cujo valor não exceder de dois contos de réis.»

«Art. 27 O Governo, além dos regulamentos e instruções de sua competência para a boa execução do Código Comercial, é autorizado para, em um regulamento adequado, determinar a ordem do Juízo no processo comercial particular, para a execução do segundo periodo do art. $1^{\circ}$ e do art. $8^{\circ}$, tendo em vista as disposições deste Título e as do Código Comercial; e, outrossim, para estabelecer as regras e formalidades que devem seguir-se nos embargos de bens, e na detenção pessoal do devedor que deixa de pagar divida comercial.»

Mesmo antes de ser promulgado o Código Comercial, o Governo já vinha cuidando da elaboração dos regulamentos adequados, a que se referiu o art. 27.

O Ministro da Justiça, Euzébio de Queiroz Coutinho Mattoso Câmara, em março de 1850, constituiu uma Comissão, por ele presidida, para preparar os regulamentos do Código, em vias de aprovação; integravam-na José Clemente Pereira, José Tomás Nabuco de Araújo, Francisco Ignacio de Carvalho Moreira, futuro Barão de Penedo, Caetano Alberto Soares e Irineu Evangelista de Sousa, futuro Barão e Visconde de Mauá.

Foram distribuídos os encargos entre os membros da Comissão. Aos três juristas, Nabuco de Araújo, Caetano Alberto e Carvalho Mo- 
reira, coube preparar os respectivos trabalhos com relação à matéria contida nas três partes do Código Comercial, de sorte que reunidos formassem um projeto completo de regulamento processual. Do título Único do Código, relativo aos Tribunais e juízes comerciais, incumbiu-se José Clemente Pereira, que redigiu o outro projeto de regulamento.

Todos êsses trabalhos foram submetidos à discussão e, ao cabo de três meses de reuniões consecutivas, a Comissão deu por cumprido o encargo.

Para a redação final, por indicação de Nabuco, foi Carvalho Moreira exclusivamente encarregado dela, convindo, dizia ele, «que fosse um só o redator para haver identidade de linguagem e de estilo na rệdação.»

Aprovados os dois projetos pelo Governo, foram promulgados pelos Decretos n's. 737 e 738, de 25 de novembro de 1850. comerciais.

O Regulamento $\mathrm{n}^{0} 737$ disciplinou o processo das causas

14.1. Os juristas que o elaboraram, como não podia deixar de acontecer, em virtude de sua formação cultural, deviam de ter em mente os ensinamentos das doutrinas dos jurisconsultos portugueses contemporâneos, não obstante porfiassem por imprimir ao trabalho cunho acentuadamente novo, segundo a técnica legislativa moderna, o que lograram realizar amplamente.

No Regulamento se manteve substancialmente inalterada a estrutura fundamental do processo do direito comum, mas, como disse Liebman, «si formularano le sue regole con grande chiarezza, in brevi e precise disposizioni, secondo la tecnica legislativa moderna.»

A superioridade do sistema processual introduzido por ele sobre o processo tradicional, formalista, complicado e moroso do Livro III das Ordenações, ainda vigente para as causas cíveis, foi desde logo reconhecida e apregoada por todos os juristas.

Com exceção do Código de Processo Cívil francês, de 1806, os principais Códigos de Processo promulgados na Europa são posteriores ao Regulamento.

Mas, posto em confronto com o Código Napoleônico que adotara orientação nova «rompendo com as fórmulas tradicionais», o Regulamento não the fica a dever muito, quanto à distribuição das matérias, precisão dos conceitos, clareza dos dispositivos e simplificação de atos e termos processuais.

Quanto a ter mantido a estrutura fundamental do processo, segundo os cânones do direito comum, os Códigos de Processo Civil italiano de 1865, o português de 1876 e a «Ley de Enjuiciamiento Civil» espanhola de 1881, também o fizeram com pequenas variações, e so- 
mente o Regulamento do processo civil alemão de 1877 apresentou um sistema inteiramente novo, desvinculado do processo do direito comum, mediante a introdução dos princípios da chamada oralidade processual.

Por todos os seus méritos, o Regulamento $\mathrm{n}^{\circ} 737$ pode ser considerado como o mais alto e mais notável monumento legislativo do Império, porventura o mais notável Código de processo publicado na América no século XIX.

O que, na verdade, se reflete no Regulamento, é «o espírito prudente dos seus autores e o espírito conservador do Governo de então», como foi argutamente observado pelo eminente mestre Frederico Carpenter.

15. Em manifesta coerência com a doutrina sustentada na famosa Memória de 1847, Carvalho Moreira introduziu no Regulamento $\mathrm{n}^{\circ} 737$ a distinção entre nulidade do processo e nulidade da sentença.

Entre as muitas normas processuais, que concorrem para qualificar aquele Regulamento como o mais aperfeiçoado Código de processo da época, a separação dos motivos de nulidade do processo dos motivos de nulidade da sentença, por suas implicações e benéficas consequências práticas, assinala um marco de progresso na legislação brasileira como conquista doutrinária no campo do direito processual civil.

Na Parte Terceira, o Título II «Das Nulidades» está dividido em três capítulos: Capítulo I «das nulidades do processo», artigos 672 a 679; Capítulo II «das nulidades da sentença», artigos 680 e 681; Capítulo III «da nulidade dos contratos comerciais», artigos 682 a 694.

A tradicional dicotomia herdada do Direito Lusitano - nulidade manifesta ou injustiça notória - que autorizava a interposição do recurso de revista nas causas cíveis, foi, então, superada nas causas comerciais.

O artigo 667 prescreve, terminantemente, que o «Supremo Tribunal de Justiça só concederá revista por nulidade do processo, ou por nulidade da sentença, nos termos declarados no Título II, Capítulo I — «Das nulidades».

A inovação representou aperfeiçoamento em relação ao recurso de revista, no processo comercial, que, agora, só podia ser interposto com fundamento em algum dos motivos de nulidade expressamente declarados nesses artigos.

Desaparecia, assim, o casuismo que presidia ao cabimento da revista no processo civil, e que fôra minuciosamente catalogado e analisado por Pimenta Bueno.

16. Segundo o disposto no artigo 680 , são quatro os motivos que acarretam a nulidade da sentença: $1^{\circ}$, ter sido dada por juiz incompetente, suspeito, peitado ou subornado; $2^{\circ}$, ter sido proferida contra expressa disposição da legislação comercial - a ilegalidade da decisão, 
e não dos motivos e enunciado dela, constitue esta nulidade; $3^{\circ}$ ter sido fundada em instrumentos ou depoimentos julgados falsos em juízo competente; $4^{\circ}$, sendo o processo em que ela foi proferida anulado em razão das nulidades referidas no capítulo antecedente.

Dos quatro motivos de nulidade da sentença, arrolados nesse artigo, o primeiro, na parte concernente à peita ou suborno do juiz, e o terceiro, referente à falsidade da prova em que se fundou a sentença, correspondem ao primeiro e segundo dos quatro casos apontados por Pimenta Bueno, antes da promulgação do Regulamento $\mathrm{n}^{\circ} 737$, para justificar o prevalecimento da ação de nulidade no direito pátrio, em face da controvérsia que grassava a respeito nos meios jurídicos.

O terceiro caso indicado por Pimenta Bueno, que se refere à «noviter reperta instrumentorum», não foi acolhido no elenco do artigo 680 como motivo de nulidade da sentença.

Carvalho Moreira, atendendo à lição de Sylva, Pereira e Sousa e Lobão, optou por colocar a descoberta de documentos novos como fundamento para os Embargos Infringentes do Julgado, que o Executado podia apresentar na execução da sentença, com suspensão dela (Emmanuellis Gonçalves da Sylva, «Commentaria ad Ordinationes Regni Portugalliae», Ulyssipone MDCCXLII, tomus tertio p. 385; JJC Pereira e Sousa, «Primeiras Linhas sobre o Processo Civil,» Lisboa 1825, tomo $3^{\circ}, \S$ CCCCXLVI nota 881; Manoel de Almeida e Souza de Lobão, Segundas Linhas sobre o Processo Civil», Lisboa 1817, $1^{\text {a }}$ parte, p. $484 \mathrm{n}^{\circ} 6$ e «Tratado Enciclopédico, Prático e Crítico, sobre as Execuções que procedem por Sentenças», Lisboa 1817, §§ 215 e 218).

Em consonância com o ensinamento desses autores portugueses, que gozavam de merecido prestígio entre os juristas brasileiros, Car valho Moreira introduziu, no Capítulo «Dos Embargos do Executado», as seguintes regras: artigo 577, «são admissíveis na execução, com suspensão dela, e propostos conjuntamente nos seis dias seguintes à penhora, os embargos:... $\S 8^{\circ}$, «Infringentes do julgado com prova incontinenti do prejuizo, sendo opostos»:.. $\mathrm{n}^{0} 3$, «Pelo executado, oferecendo documentos obtidos depois da sentença».

Artigo 579, «São admissíveis na execução das ações reais os seguintes embargos»:... $4^{\circ}$, «Infringentes do julgado com prova produzida incontinenti, sendo opostas»:... $\mathrm{n}^{\circ} 3$, «Pelo executado com documentos havidos depois da sentença».

O segundo motivo de nulidade da sentença, previsto no artigo 680, reproduziu no âmbito do processo comercial a velha norma das Ordenações do Livro Terceiro, Título 75 , a propósito da sentença dada contra direito expresso.

O quarto motivo, finalmente, era uma consequência normal e necessária, que decorria do fato de ter sido anulado o processo em que fora proferida a sentença. 
Pimenta Bueno arrolara «a falta ou falsidade da primeira citação» como o quarto caso de nulidade da sentença.

No Regulamento, porém, a primeira citação pessoal na causa principal e na execução (Título Único, artigo 24) foi considerada como termo essencial do processo comercial (artigo 673, § $2^{\circ}$ ), cuja falta importa em nulidade do processo (artigo 672, $\S 2^{\circ}$ ), o que é mais adequado.

A descoberta de documento novo, que no Regulamento foi ad. mitida como fundamento para os Embargos Intringentes do Julgado, oponiveis pelo executado na execução da sentença, persistiu com essa finalidade no regime seguinte, dos Códigos de Processo estaduais (Santa Catarina, art. 1.808, VII, b; Paraná, art. 662, $\mathrm{n}^{\circ} 3$, b; São Paulo, art. 1.056, $\mathrm{n}^{\circ}$ 11; Minas Gerais, art. 1.400, $\mathrm{n}^{\circ} 3$; Bahia, art. 1.192, $\mathrm{n}^{\circ} 4$, c; Pernambuco, art. 1.393, $\left.\mathrm{n}^{\circ} 5, \mathrm{~b}\right)$, sendo que os Códigos do Ceará, art. $1.303, \mathrm{n}^{\circ} \mathrm{IV}$, e de Pernambuco, art. $173, \mathrm{n}^{\circ} 6$, acolheram o princípio da «noviter reperta instrumentorum» como motivo autônomo de nulidade da sentença, a ser arguido em ação rescisória, segundo o pronunciamento doutrinário de Pimenta Bueno.

17. Depois de ter indicado no artigo 680 os quatro motivos de nulidade da sentença, o Regulamento dispõe, no artigo 681, que a sentença pode ser anulada mediante o emprego dos meios especificados nos seus quatro parágrafos, que são os seguintes: § 1\%, apelação; $\S 2^{\circ}$, revista; $\S 3^{\circ}$, embargos à execução; $\S 4^{\circ}$, a ação rescisória, não sendo a sentença proferida em gráu de revista.

Os meios de impugnação da sentença nula estão designados numa sequência escalonada, que abrange os dois recursos específicos contra a sentença de primeira instância (apelação) e contra o acórdão do Tribunal da Relação (revista), que se interpõem antes da decisão transitar em julgado, e os dois remédios especiais admitidos contra a sentença (embargos à execuçãọ) e contra o acórdão (ação rescisória), depois da decisão ter transitado em julgado.

Quanto aos dois recursos, apelação e revista, o Regulamento em nada inovou, pois, limitou-se a transladar para o âmbito do processo comercial as normas tradicionais que disciplinam a função processual daqueles meios de impugnação do julgado no processo civil, apenas, com algumas modificações concernentes ao procedimento da apelação (artigos 646 a 661), o que, entretanto, não ocorreu em relação à revista, tendo o artigo 666 estabelecido que «a interposição da revista nas causas comerciais, a remessa dos autos e o julgamento do recurso no Supremo Tribunal serão regulados pelo mesmo modo que nas causas cíveis».

A verdadeira e importante inovação consistiu na introdução da ação rescisória, no processo comercial, como meio autônomo e especia] de impugnação da sentença nula, depois dela ter transitado em julgado. 
Em face da controvérsia doutrinária sobre a existência, no direito brasileiro, da ação de nulidade em concorrência com o Recurso de Revista, e particularmente, quanto à possibilidade de ser a ação proposta depois do julgamento da revista pelo Supremo Tribunal de Justiça, o emérito redator do Regulamento pôs termo à discussão e resolveu a dúvida, mediante a disposição peremptória do $\S 4^{\circ}$, do artigo 681, que prescreve a possibilidade de a sentença ser anulada por meio da ação rescisória, «nã̃o sendo a sentença proferida em gráu de revista».

Com semelhante dispositivo Carvalho Moreira acolheu, em parte, a opinião brilhantemente sustentada por Pimenta Bueno a respeito da necessidade de ser reconhecida a sobrevivência da ação de nulidade no direito brasileiro, agora denominada ação rescisória, mas limitou-a, no sentido de não atingir as decisões proferidas pelo Supremo Tribunal de Justiça no julgamento do Recurso de Revista nas causas comerciais.

Foi a consagração legislativa da tese propugnada na célebre $\mathrm{Me}$ mória de 1847 e no Projeto de lei para a reforma do Supremo Tribunal de Justiça, cujo artigo 12 prescrevia ser definitivo o julgamento da revista pelo Supremo e suas decisões irrevogáveis.

Tese eminentemente conservadora, a confirmar a sutil observação do professor Frederico Carpenter sobre o espírito do velho Regulamento.

Na verdade, a despeito da sábia advertência de Pimenta Bueno, com esse dispositivo o julgamento do Supremo Tribunal era alçado à categoria de absoluto.

18. O Regulamento não estabeleceu regras particulares para o processamento da ação rescisória.

Considerada como uma ação comum, não obstante sua finalidade ser o ataque à sentença transitada em julgado, com a função de desconstituir sua eficácia por motivo de nulidade (artigos 680 e 681, § $4^{\circ}$ ), o processo era o ordinário, segundo o disposto no Título II, «Da Ordem do Juizo», Capitulo IV, «Da ação ordinária e sua proposição», cujo artigo 65 estabelece: «Esta ação é competente em todas as causas para as quais não estiver neste Regulamento determinada alguma ação sumária, especial ou executiva».

Como tal, deve ser proposta no fôro do domicílio do réu, artigo 60 , e seguir os trâmites estabelecidos para o processo ordinário, no citado Título II do Regulamento, que a exemplo das Ordenações do Reino (Filipinas, Livro III, Título XX, ainda em vigor e disciplinando o processo civil) ostenta a tradicional epígrafe «Da ordem do juizo», e indica em dispositivos claros, precisos e minuciosos, o procedimento a ser observado na prática dos atos e termos do processo, desde a tentativa da conciliação até a sentença definitiva (artigos 23 a 235).

Contra a sentença cabem os recursos previstos na Parte Terceira, Título I, «Dos recursos»: Capítulo I, «Dos Embargos» artigos 639 a 
645; Capítulo II, «Das apelações» artigos 646 a 661, e os Embargos nas Relações artigos 662 a 664; Capítulo III, «Da Revista» artigos 665 a 667; Capítulo IV, «Dos agravos» artigos 668 a 671.

Salvo no caso de julgamento da ação rescisória em gráu de revista, nada impede a propositura de uma nova ação rescisória contra a sentença proferida na ação rescisória anterior, desde que tenha se verificado a ocorrência de algum dos motivos de nulidade arrolados no artigo 680 .

Nessa hipótese a rescisória só pode versar sobre matéria nova, excluindo-se de seu âmbito tudo que foi objeto de apreciação e julgamento pela sentença proferida na ação rescisória anterior.

A regra proibitiva da ação rescisória contra a sentença (acórdão) proferida em gráu de revista, que era restrita às causas comerciais, passou a ser observada nas causas cíveis por força da interpretação analógica firmada pela jurisprudência do Supremo Tribunal, a partir de 1878.

19. Durante quarenta anos (1850 a 1890) coexistiram nas lides forênses, lado a lado, dois sistemas processuais: o velho sistema herdado do Livro Terceiro das Ordenações Filipinas, co mas normas específicas do Título XX, a disciplinarem a Ordem do Juizo no processo das causas cíveis, com as modificações introduzidas pela Disposição Provisória acerca da Administração da Justiça Civil, de 29 de novembro de 1832 e pela Lei $n^{\circ} 261$ de 3 de dezembro de 1841 e seu Regulamento o Decreto $\mathrm{n}^{\circ} 143$, de 15 de março de 1842 , e o novo sistema instituído pelo Regulamento $\mathrm{n}^{\circ} 737$, de 1850 , para o processo das causas comerciais.

A superioridade do sistema comercial, que Paula Baptista havia demonstrado no «Compêndio de Teoria e Prática do Processo Civil comparado com o Comercial», editado em 1855, era admitida e proclamada por todos que militavam no fôro.

Em 8 de novembro de 1882, o Governo nomeou os juristas Conse lheiro Lafayette Rodrigues Pereira, Desembargador Olegário Herculano de Aquino e Castro e Deputado Leandro de Chaves Mello Ratisbona para constituirem a Comissão encarregada de organizar um trabalho sobre a administração da justiça e pessoal da magistratura, destinado a servir de base ao Projeto de reforma judiciária que o Governo pretendia submeter à consideração do Poder Legislativo.

$\mathrm{Na}$ parte referente ao processo civil, a Comissão limitou-se a propor a substituição do sistema vigente pelo Regulamento Comercial $\mathrm{n}^{\circ}$ 737, que deveria ser aplicado «com as necessárias modificações» (Projeto II, artigo 24, $\mathrm{n}^{\circ}$ ), refletindo a opinião generalizada dos juristas.

A proposta, contudo, só veio a ser acolhida pelo legislador republicano em 1890. 
No que respeita à revogação da sentença por motivo de nulidade, a diferença mais importante entre os dois sistemas residia em que o Recurso de Revista, no processo civil, só era admitido nos casos de manifesta nulidade ou injustiça notória (Lei de 18 de setembro de 1828, art. 6\%) o que impunha aos advogados brasileiros, como já foi dito anteriormente «a ingente tarefa de enquadrar em algum desses dois gêneros os casos ocorrentes na prática, para possibilitar a interposição do recurso», enquanto no processo comercial o recurso só será concedido pelo Supremo Tribunal por nulidade do processo, ou por nulidade da sentença, nos termos declarados no Título II, Capítulo «Das nulidades», (artigo 667) ou seja, naqueles casos taxativamente enunciados.

No processo civil, que continuava regido pelas normas do Livro III, das Ordenações Filipinas, vigia o princípio estabelecido no Título LXXV, que a sentença que é por direito nenhuma, nunca em tempo algum passa em coisa julgada, mas em todo tempo se pode opor contra ela, que é nenhuma e de nenhum efeito, e por tanto não é necessário ser dela apelado.

Princípio tradicional no Direito Lusitano (Afonsinas, Liv. III Tit. LXXVIII, Manuelinas, Liv. III Tit. LX) que não foi revogado pelas leis brasileiras, como Pimenta Bueno demonstrou.

Assim, consoante a expressa determinação daquele Título, «é por Direito a sentença nenhuma, quando é dada sem a parte ser primeiro citada, ou é contra outra sentença já dada, ou foi dada por peita ou preço que o juiz houve, ou por falsa prova, ou se eram muitos juizes delegados, alguns deram sentença sem os outros, ou se foi dada por juiz incompetente em todo, ou em parte, ou quando foi dada contra direito expresso, assim como se o juiz julgasse diretamente que 0 menor de quatorze anos podia fazer testamento, ou podia ser testemunha, ou outra coisa semelhante, que seja contra nossas Ordenações, ou contra Direito expresso».

Em seguida, no número I, vem consignada a importante norma que a sentença, que de princípio foi nenhuma, por nenhum ato seguinte pode ser confirmada. «E posto que de tal sentença seja apelado, não será por isso feita por Direito valiosa, ainda que a apelação pareça ato aprovativo dela, pelo qual parece o apelante aprovar a tal nulidade; porque pois a sentença de princípio foi nenhuma, já por nenhum ato seguinte pode ser confirmada, salvo por nós de certa ciência, porque o Rei é Lei animada sobre a terra e pode fazer Lei e revogá-la, quando vir que convem fazer-se assim».

$\mathrm{E}$ com base nesse princípio fundamental que a doutrina dos juristas lusitanos, a partir de Alvaro Valasco, sustentou a coexistência do remédio ordinário «per viam nullitatis» com o Recurso de Revista contra a sentença eivada de nulidade, o qual podia ser utilizado mesmo depois do julgamento da revista, de que trata o Título XCV, uma vez que a sentença nula nunca transitava em julgado e em todo tempo se pode opor contra ela. 
E foi fundado nessa doutrina que Pimenta Bueno defendeu a sobrevivência, no direito brasileiro, da ação de nulidade do julgado, naqueles quatro casos por ele superiormente examinados.

A ação de nulidade da sentença civil devia ser proposta no fôro do domicílio do réu e seguir todos os trâmites traçados para o processo ordinário no Título XX, do Livro III.

O velho sistema processual das Ordenações, do Livro III, foi abolido, nos primórdios do regime republicano, quando o Decreto $\mathrm{n}^{\circ} 763$, de 19 de setembro de 1890, do Governo Provisório, mandou observar no processo das causas cíveis em geral o Regulamento $\mathrm{n}^{\circ} 737$, de 25 de novembro de 1850, com algumas exceções, declaradas no seu artigo $1^{\circ}$, que são as seguintes: todas as normas contidas no Título I, no capítulo I do Título II, nos capítulos IV e V do Título IV, nos capítulos II, III e IV e secções I e II do capítulo V do Título VII e no título VIII da primeira parte.

Assim, não têm aplicação no processo civil os artigos 1 a 22 (Título I) que dispõem sobre a conciliação; os artigos 23 a 38 (Título II) que dispõem sobre a conciliação; os artigos 289 a 298 (capítulo IV) que dispõem sobre as soidadas e artigos 299 a 307 (capitulo V) que dispõem sobre seguros todos do Título IV; os artigos 343 a 350 (capítulo II) que dispõem sobre a detenção pessoal, os artigos 351 a 357 (capítulo III) que dispõem sobre a exibição, os artigos 358 e 359 (capítulo IV) que dispõem sobre as vendas judiciais, os artigos 360 a 369 (secção I do capítulo V) e os artigos 370 a 389 (secção II do capítulo V) todos do Título VII; os artigos 411 a 475 (Título VIII, primeira parte) que dispõem sobre o juizo arbitral.

Expurgado dessas normas, que foram consideradas inadequadas para o processo das causas cíveis em geral, o Regulamento tornou-se um verdadeiro Código do Processo Civil que esteve em vigor em todo o país, e, depois da Constituição Federal de 1891, nos Estados, até que fossem promulgados os seus respectivos Códigos de processo. Em alguns Estados, que não chegaram a editar seus Códigos de processo (Alagoas, Amazonas, Goiás e Mato Grosso) o Regulamento teve vigência até a promulgação do Código de Processo Civil Brasileiro (Decreto-Lei $\mathrm{n}^{9}$ 1.608, de 18 de setembro de 1939. (Uma permanência de 89 anos.

Dos Códigos Estaduais que o sucederam, o primeiro, do Rio Grande do Sul, durou 31 anos, e os dois últimos, de São Paulo e da Paraiba, 9 anos, O primeiro Código nacional não passou dos 34 anos. Veremos a quantos chegará o atual, nesta época tomada de incoercível prurido legiferante! 